\title{
Comparative Evaluation of the Implementation of Quality Assurance Mechanisms in Educational Management Programme of Universities in South-East, Geo-Political Zone of Nigeria
}

\author{
Paul Nwakpa \\ Department of Educational Foundations \\ Faculty of Education, Ebonyi State University \\ Abakaliki, Nigeria \\ Email: bropaulnwaoo [AT] gmail.com
}

\begin{abstract}
This study focused on comparative evaluation of the implementation of quality assurance mechanisms in educational management programme of public and private universities in South-East Geo-political zone of Nigeria. The study was guided by four research questions and four null hypotheses. The study was carried out in three private and eight public universities running educational management programme. The study adopted a survey research design. The population of the study was eleven heads of departments of the eleven universities. A questionnaire instrument constructed by the researcher was used to collect data for the study, titled, "Questionnaire on comparative evaluation of the implementation of quality assurance mechanisms in educational management programme of universities in South-East of Nigeria (QCEI QAMEMPUSEN). The instrument was face-validated by three experts in the department of Educational Foundations of Ebonyi State University. The reliability of the instrument was obtained using cronbach alpha reliability coefficient, and it yielded 0.83 . Mean scores of the respondents were used to answer the four research questions while $\mathrm{t}$ test was used to answer the four null hypotheses at 0.05 level of significance. The study came up with some major findings to include, that both types of universities (public and private universities) in South-East implementation the four major mechanisms for quality assurance in educational management programme to a little extent, but the private universities seem to record better implementation of the four mechanisms compared to the public universities. The study then recommended among others that the National Universities Commission (NUC) should lay more emphasis on the public universities especially during main accreditation exercise of universities, as to reduce the gap that exists in the standard in both types of institutions.
\end{abstract}

Keywords--- Comparative, Evaluation, Quality, Assurance, Mechanisms, Educational Management and Programme

\section{INTRODUCTION}

University is the highest level in the education ladder. The university is made up of people with different backgrounds in terms of skills, needs, talents, status, competencies, knowledge, behavioural styles, interest and perceptions (Nakpodia, 2003). The skills and high level manpower needed for economic and political growth and development of any economy are produced by the universities. Universities as learning organizations are centers of excellence, teaching, research and store of knowledge.

According to the Federal Government of Nigeria (FGN) (2004), university education shall make optimum contribution to national development by:

1) Intensifying and diversifying its programmes for the development of higher level manpower within the context of the needs of the nation;

2) Making professional courses' contents to reflect the national requirements;

3) Making all students, as part of a general programme of all-round improvement in university of education, to offer general study courses such as history of ideas, philosophy of knowledge and nationalism ;

4) University research shall be relevant to the nation's developmental goals; in this regard, universities shall be encouraged to disseminate their research to both government and industries;

5) University teaching shall seek to inculcate community spirit in the students through project and action research.

Universities run so many programmes at various levels. Educational management programme which is a sub-set of the university education and like other programmes of the university is specifically for the training of education administrators, education managers, education supervisors, teachers and policy makers in education. 
Educational management is that aspect of educational training which an individual receives with the primary motive of enabling one to acquire adequate attitudes, concepts, knowledge, understanding and skills in school management activities for usage in careers as an educational administrator, educational manager, supervisor, teacher wherever one might find him/herself in the society.

The objectives of educational management programme according Unizik, Educational Management and Policy include the following:

1) Provide highly motivated conscientious and efficient education managers for all levels of the education system.

2) Encourage further the spirit on enquiry and creativity in teachers.

3) Help educational managers to fit into the social life of the community and society at large and enhance commitment to national objectives.

4) Provide educational managers with the intellectual and professional background adequate for their assignment and to make them adaptable to any changing situation not only in the life of their country but also in the wider world.

5) Enhance teachers' commitment to the teaching profession to make them adequate for their assignments and to make them adaptable to any changing situation.

6) Produce highly efficient and conscientious classroom teachers who would manage classrooms in a way that will motivate and enhance learning.

7) Develop skills and knowledge of those who will manage the education system, and

8) Prepare various categories of workers in the education industry for further studies in management.

Education just like every other organization has set goals and objectives that need to be achieved, and to do that, there is need to ensure quality and sustainable standards in the educations system. Hence, it becomes imperative to check and evaluate the mechanisms for quality assurance in educational management programmes.

Quality assurance in education system implies the ability of the institution to meet the expectations of the user of manpower in relation to quality of skills acquired by their output (Ajayi and Akindutize, 2007) Oladipo, Adeosun and Oni (2009) posited that educational programme could be measured in terms of quality of input, quality of process, quality of content and quality of output.

Therefore, to ensure quality educational management, it requires the right quantity and quality in everything that goes into the teaching-learning process or systems as input and process. For educational management to be accorded its respect in our society, Okebukola (2011) noted that it must provide graduates with minimum skills that will enable them to be self-reliant and useful to the society. It is on record that Nigerian universities have been producing high quality graduates in far past.

Daisi in Oladipo (2009) opined that many graduates from Nigerian universities have distinguished themselves in their areas of specialization so much that some of them are now professors in the best universities across the globe. One cannot doubt the fact that the university education system has enhanced social, cultural, economic, political, scientific and technological progress in Nigeria.

Nigeria is more blessed now with specialists at various fields of endeavour: medicine, law, engineering, philosophy, education, etc. Due to this development, the country is becoming more and more dynamic and self -reliant as the days go by. With the establishment of at least one federal university in every state of the federation, in recent time, without proper care and monitoring, a lot of failures have been recorded.

Okebukola (2011) decried the quality of graduates produced in Nigerian tertiary institutions especially in the last four years and thumbed down the quality of those that would graduate in three years time. Similarly, Ekumayo (2012) submitted that the non-inclusion of any of the Nigerian's universities in the world best 1,500 universities is unsavory and worse still, Nigeria ranked number 22 after South Africa, Egypt, Ghana and Kenya in the ranking of African universities.

The NUC (2014) assessment study on the labour market expectations of graduates from Nigerian universities revealed that there were scores of unemployed graduates roaming the streets and more embarrassing, those who were lucky to secure employment had to undergo remedial training in order to bridge the huge knowledge and skill gaps leftover from university training. The recent developments in the Nigerian university system and its poor rankings in Africa and the world in general shows that all is not well as expected with ensuring quality in the Nigeria university system. Educational management programme is not left out of this deplorable state. The major objective of educational management is to produce education managers for all levels of education. Most managers at the top levels of various education systems are not experts in educational management, as some of them climb the ladder of leadership either by promotion on the basis 
of years of experience or by appointment (Adegbesam, 2011). According to Anioke (2010) until expertise positions are reserved for only qualified personnel, the system will continue to suffer degration.

Due to the declining quality in recent year the accolade attached to Nigerian universities seem to be fading away fast. This is informed by the flood of criticisms that beclouded the quality of graduates produced. Parents now seek alternative for their children's education in South Africa and even Ghanaian universities and even beyond.

This ugly situation in Nigeria tends to negate the tenet of quality university education which is essentially an industry established to produce high quality workforce for national development. It is against this background that National University Commission (NUC) (2010) identified the following mechanisms for quality assurance in Nigeria educational system to salvage the deplorable situation. They are: (1) Moderation of examination (2) In-service professional development given to career academics (3) Proper funding of education (4) Supervision and inspection (5) Infrastructural evaluation (6) Mentoring and monitoring (7) Mock accreditation exercise (8) Regular evaluation of the system among others

However, this study evaluated four major mechanisms which are: moderation of examinations; in-service professional development programmes, mock accreditation exercise and adequate infrastructural facilities. These mechanisms, already existing in schools are contained under the criteria for accrediting a degree programme, as a policy, in relevant areas of section 8.0 of the NUC's, 2010 manual of accreditation procedures for academic programmes in Nigeria. It is believed that when these mechanisms are properly implemented in the institutions, it will bring about quality and thereby lead to high standard of university education in the country.

Although, all the universities in Nigeria are regulated by NUC, implementation procedures of these mechanisms seem to differ with respect to public and private universities which were the focus of this study. It is based on these that this study sought to access the extent of the implementation of quality assurance mechanisms in educational management programme of public and private universities in South-East Nigeria.

\section{STATEMENT OF THE PROBLEM}

It is on record that the standard of education in Nigeria generally has declined right from the primary level to tertiary level. It is very worrisome that a graduate of a university in Nigeria cannot construct good sentences in English language, and thus cannot fit in well in the work place due to deficiencies in the school systems. It is observed that Nigerian universities established for high quality education for national development are no longer living up to expectations. This ugly situation has also been noticed in the private universities also. Parents run to private universities with the hope for better education for their children but the story about poor quality of education is not different. This study then wanted to establish the extent these two types of universities implement the NUC's regulations in terms of: (1) Examination moderation (2) In-service professional development programmes (3) Provision of infrastructural facilities and (4) Mock accreditation exercise and finally to offer suggestions for better performances.

\section{SIGNIFICANCE OF THE STUDY}

The findings of this study will be beneficial to the students; parents and the government. The students will stand to benefit from the findings of this study when the recommendations of the study are implemented, in the sense that all the bottle-necks to quality education are removed; the students will then be taught well, and skills imparted.

The parents who invest on their children will benefit in the sense that their children will come out from universities with appropriate skills, be employable, useful to themselves to their parents and the society at large. The government will also gain from this study by having quality workforce for national development which is the major reason for establishing universities in the country.

\section{RESEARCH QUESTIONS}

Four research questions guided the study.

1) To what extent is moderation of examinations as a mechanism for quality assurance in educational management programme being implemented in public and private universities in South-East Nigeria?

2) To what extent is in-service professional development programmes as a mechanism for quality assurance in educational management programme being implemented in public and private universities in South-East Nigeria?

3) To what extent is mock accreditation exercise as a mechanism for quality assurance in educational management programme being implemented in public and private universities in South-East Nigeria? 
4) To what extent is the adequacy of infrastructural facilities as a mechanism for quality assurance in educational management programme being implemented in public and private universities in South-East Nigeria?

\section{HYPOTHESES}

Four null hypotheses guided the study.

1) There is no significant difference in the mean ratings of respondents on the extent of implementation of moderation of examinations as a mechanism for quality assurance in educational management programme in public and private universities in South-East Nigeria.

2) Public and private universities in South-East Nigeria do not differ significantly in their mean ratings on the extent of implementation of in-service professional development programmes as a mechanism for quality assurance in educational management programme of universities.

3) There is no significant difference in the mean ratings of public and private universities on the extent of implementation of mock accreditation exercise as mechanism for quality assurance in educational management programme being implemented in public and private universities in South-East Nigeria?

4) Public and private universities do not differ significantly in their mean ratings on the extent of provision of adequate infrastructural facilities as a mechanism for quality assurance in educational management programme of universities.

\section{METHODOLOGY}

The study adopted ex-post factor research design which focused on comparative evaluation of the implementation of quality assurance mechanisms in educational management programme of public and private universities in South-East of Nigeria. Four research questions and four null hypotheses guided the study. The study was carried out in eight public and three private universities in South-East Nigeria that run educational management programme. The population size used for the study was eleven heads of departments who responded to the questionnaire instrument. The questionnaire instrument contained 44 items as they relate to: moderation of examinations; in-service professional development programmes; mock accreditation exercise, and adequacy of infrastructural facilities provided. The instrument was validated by three experts in the department of Educational Foundations, Ebonyi State University, Abakaliki. A grand reliability index of 0.88 was obtained using cronbach alpha. 4 point scales of Very Great Extent (VGL) 4 point, Great Extent (GE) 3 points; Less Extent (LE) 2 and Very Less Extent (VLE) 1 point was used in allocating values to responses. Mean scores were used to answer the four research questions while t-test was used to test the four null hypotheses at 0.05 level of significance.

\section{RESULTS}

The results of the study are presented sequentially in tables starting from research question one to test of the null hypotheses.

Research Question One: To what extent is moderation of examinations as a mechanism for quality assurance in educational management programme being implemented in public and private universities in South-East Nigeria?

Table 1: mean scores of HODs' responses on extent of implementation of moderation of examinations as a mechanism for quality assurance in educational management programme of public and private universities in South-East, Nigeria.

\begin{tabular}{|c|c|c|c|c|c|}
\hline \multirow[t]{2}{*}{$\mathbf{S} / \mathbf{N}$} & \multirow[t]{2}{*}{ Items on Moderation of Examination } & \multicolumn{2}{|c|}{ Public Universities } & \multicolumn{2}{|c|}{ Private Universities } \\
\hline & & Mean & Decision & Mean & Decision \\
\hline 1. & Moderation of examination questions & 2.06 & LE & 2.52 & GE \\
\hline 2. & Moderation of marking scheme & 2.26 & LE & 2.61 & GE \\
\hline 3. & Moderation of answer scripts & 1.37 & VLE & 2.65 & GE \\
\hline 4. & Moderation of C.A scores & 1.23 & VLE & 1.55 & LE \\
\hline 5 . & Moderation of exam results & 2.30 & LE & 3.04 & GE \\
\hline 6. & Moderation of students' research projects & 1.37 & VLE & 2.70 & GE \\
\hline \multirow[t]{2}{*}{7.} & $\begin{array}{l}\text { Moderation of course contents and scheme } \\
\text { of work }\end{array}$ & 1.45 & VLE & 2.66 & GE \\
\hline & Grand mean (x) - & 1.72 & & 2.53 & \\
\hline
\end{tabular}

Research Question Two: To what extent is in-service professional development programmes as a mechanism for quality assurance in educational management programme being implemented in public and private universities in South-East Nigeria? 
Table 2: Mean scores of HODs' responses on extent of implementation of in-service professional development programme as a mechanism for quality assurance in educational management programme of public and private universities in SouthEast, Nigeria.

\begin{tabular}{|c|c|c|c|c|c|}
\hline \multirow[t]{2}{*}{$\mathbf{S} / \mathbf{N}$} & \multirow{2}{*}{$\begin{array}{l}\text { Items on In-Service Professional } \\
\text { Development Programme }\end{array}$} & \multicolumn{2}{|c|}{ Public Universities } & \multicolumn{2}{|c|}{ Private Universities } \\
\hline & & Mean & Decision & Mean & Decision \\
\hline 8. & $\begin{array}{l}\text { Mentoring of newly employed staff by old } \\
\text { staff }\end{array}$ & 1.81 & VLE & 1.62 & VLE \\
\hline 9. & Attendance to conferences & 2.68 & GE & 2.04 & LE \\
\hline 10. & Promoting consultation for staff & 2.00 & LE & 2.31 & LE \\
\hline 11. & Technical assistance to new staff & 1.88 & VLE & 1.35 & VLE \\
\hline 12. & Organizing and attending seminars & 2.07 & LE & 2.04 & LE \\
\hline 13. & Participating in workshops & 1.84 & VLE & 1.61 & VLE \\
\hline 14. & Organizing demonstration lessons & 1.77 & VLE & 1.30 & VLE \\
\hline 15. & Attendance to train-the-trainer programme & 1.08 & VLE & 1.00 & VLE \\
\hline \multirow[t]{2}{*}{16.} & $\begin{array}{l}\text { Attending academic event (inaugural } \\
\text { lectures) }\end{array}$ & 2.16 & $\mathrm{LE}$ & 1.06 & VLE \\
\hline & Grand mean $(x)$ & 1.92 & & 1.59 & \\
\hline
\end{tabular}

Research Question Three: To what extent is mock accreditation exercise as a mechanism for quality assurance in educational management programme being implemented in public and private universities in South-East Nigeria?

Table 3: Mean scores of HODs' responses on extent of implementation of mock accreditation exercise as a mechanism for quality assurance in educational management programme of public and private universities in South-East, Nigeria.

\begin{tabular}{llllll}
\hline S/N & Items on Mock Accreditation Exercise & \multicolumn{2}{l}{ Public Universities } & \multicolumn{2}{l}{ Private Universities } \\
& & Mean & Decision & Mean & Decision \\
\hline 17. & Conducive lecture halls & 2.33 & LE & 3.00 & GE \\
18. & Conducive staff offices & 2.73 & GE & 3.04 & GE \\
19. & Well equipped computer lab & 1.40 & VLE & 2.00 & LE \\
20. & Well equipped library & 2.56 & GE & 261 & GE \\
21. & Examination halls & 3.07 & GE & 3.16 & GE \\
22. & Students hostel & 2.69 & GE & 3.09 & GE \\
23. & Staff canteen/cateteria & 2.73 & GE & 2.80 & GE \\
24. & Students canteen/cateteria & 2.60 & GE & 2.76 & GE \\
25. & Toilet facilities for students & 1.69 & LE & 2.66 & GE \\
26. & Recreational facilities & 1.34 & VLE & 1.04 & VLE \\
27. & Conducive classroom & 2.65 & GE & 2.77 & GE \\
& Grand mean $(\mathbf{x})$ & $\mathbf{2 . 3 4}$ & & $\mathbf{2 . 6 3}$ & \\
\hline
\end{tabular}


Research Question Four: To what extent is the adequacy of infrastructural facilities as a mechanism for quality assurance in educational management programme being implemented in public and private universities in South-East Nigeria?

Table 4: Mean scores of HODs' responses on level of adequacy of infrastructural facilities provided as a mechanism for quality assurance in educational management programme of public and private universities in South-East, Nigeria.

\begin{tabular}{llllll}
\hline S/N & Items on Infrastructural Facilities & \multicolumn{2}{l}{ Public Universities } & \multicolumn{2}{l}{ Private Universities } \\
& & Mean & Decision & Mean & Decision \\
\hline 28. & Conducive lecture halls & 2.33 & LE & 3.00 & GE \\
29. & Conducive staff offices & 2.73 & GE & 3.04 & GE \\
30. & Well equipped computer lab & 1.40 & VLE & 2.00 & LE \\
31. & Well equipped library & 2.56 & GE & 261 & GE \\
32. & Examination halls & 3.07 & GE & 3.16 & GE \\
33. & Students hostel & 2.69 & GE & 3.09 & GE \\
34. & Staff canteen/cateteria & 2.73 & GE & 2.80 & GE \\
35. & Students canteen/cateteria & 2.60 & GE & 2.76 & GE \\
36. & Toilet facilities for students & 1.69 & LE & 2.66 & GE \\
37. & Recreational facilities & 1.34 & VLE & 1.04 & VLE \\
38. & Conducive classroom & 2.65 & GE & 2.77 & GE \\
& Grand mean (x) & $\mathbf{2 . 3 4}$ & & $\mathbf{2 . 6 3}$ & \\
\hline
\end{tabular}

HO1: There is no significant difference in the mean ratings of respondents on the extent of implementation of moderation of examinations as a mechanism for quality assurance in educational management programme in public and private universities in South-East Nigeria.

Table 5: T-test comparison of mean ratings of public and private universities

\begin{tabular}{llllllll}
\hline University type & $\mathbf{N}$ & $\mathbf{( x )}$ & SD & DF & t-cal & t-crit & Decision \\
\hline Public & 8 & 1.72 & 0.57 & 9 & & 1.96 & HO $_{1}$ : Not rejected. \\
Private & 3 & 2.53 & 0.60 & & 1.34 & &
\end{tabular}

$\mathrm{HO}_{2}$ : Public and private universities in South-East Nigeria do not differ significantly in their mean ratings on the extent of implementation of in-service professional development programmes as a mechanism for quality assurance in educational management programme of universities.

Table 6: T-test comparison of mean ratings of public and private universities.

\begin{tabular}{llllllll}
\hline University type & N & $(\mathbf{x})$ & SD & DF & t-cal & t-crit & Decision \\
\hline Public & 8 & 1.92 & 0.90 & 9 & & 1.96 & $\mathrm{HO}_{2}$ : Not rejected. \\
Private & 3 & 1.59 & 0.40 & & 0.57 & &
\end{tabular}

HO $_{3}$ : There is no significant difference in the mean ratings of public and private universities on the extent of implementation of mock accreditation exercise as mechanism for quality assurance in educational management programme being implemented in public and private universities in South-East Nigeria?

Table 7: T-test comparison of mean ratings of public and private universities

\begin{tabular}{llllllll}
\hline University type & $\mathbf{N}$ & $\mathbf{( x )}$ & SD & DF & t-cal & t-crit & Decision \\
\hline Public & 8 & 2.34 & 0.59 & 9 & & 1.96 & $\mathrm{HO}_{3}$ : Not rejected. \\
Private & 3 & 2.63 & 0.68 & & 0.67 & &
\end{tabular}

HO4: Public and private universities do not differ significantly in their mean ratings on the extent of provision of adequate infrastructural facilities as a mechanism for quality assurance in educational management programme of universities. 
Table 8: T-test comparison of mean ratings of public and private universities.

\begin{tabular}{llllllll}
\hline University type & $\mathbf{N}$ & $\mathbf{( x )}$ & SD & DF & t-cal & t-crit & Decision \\
\hline Public & 8 & 2.34 & 0.59 & 9 & & 1.96 & HO $_{4}:$ Not rejected. \\
Private & 3 & 2.63 & 0.68 & & 0.84 & &
\end{tabular}

\section{SUMMARY OF MAJOR FINDINGS}

From table 1 above, going by their grand mean scores, it was observed that public universities scored a grand mean of 1.72 indicating very less extent in implementing moderation of examinations, while private universities with a grand mean of 2.53 indicates great extent in implementing moderation of examinations. Thus, it then means that private universities take students' examinations more seriously than public universities in South-East, Nigeria.

From table 2 above, public universities with a grand mean of 1.92 and that of private universities with a grand mean of 1.59 shows that both types of schools do not take in-service professional development programmes of their staff seriously at all.

Results in table 3 show that public universities have a grand mean of 2.34 while private universities have a grand mean of 2.63. This shows that private universities take mock accreditation more seriously than public universities.

Results in table 4 indicate that public universities have a grand mean of 2.34 while private universities have a grand mean of 2.63. This shows that private universities provide infrastructural facilities to great extent, while public universities provide infrastructural facilities to less extent generally.

Result in table 5 shows that there is no significant difference in the mean scores or ratings of public and private universities on extent of implementation of moderation of examinations in both schools. Thus, hypothesis one stands accepted.

Result in table 6 shows that there was no significant difference in the mean ratings of public and private universities on extent of implementation of in-service professional development programmes. Thus, hypothesis two stands accepted.

Result in table 7 shows that there is no significant difference in the mean ratings of public and private universities on extent of implementation of mock accreditation. Thus, hypothesis three stands accepted. Finally, result in table eight shows that there was no significant difference in the mean ratings of public and private universities on extent of adequate provision of infrastructural facilities. Thus, hypothesis four stands accepted.

\section{DISCUSSION OF FINDINGS}

The results of the study show that both public and private universities in South-East Nigeria have negative attitudes towards implementing the NUC's recommended rules and regulations. These negative attitudes were more noticed in public universities than in private universities where more attention was given to moderation of examinations. These negative attitudes demonstrated by both types of universities is in conformity with the idea of Ezeani and Eze (2010) that even though the school management sees these measures as veritable in ensuring quality of the school system, in most cases, they tend to continue with those they find easy and abandon others.

The result also shows that public and private universities implement in-service professional development programme to a low extent. In support of this finding, Akam and Obi (2005) observed that most university programmes during the period of accreditation exercise engage in various measures like; moderation of examinations, provision of infrastructural facilities, adequate fund for expenditure and so on. Immediately after accreditation exercise, most of these mechanisms are abandoned, which in turn lead to fallen standard of the entire system. Qiang and Shiyan (2007) lamented that it is a well known fact that most of the highest institutions that offer education management programme suffer from shortage of teachers. Also the excessive workload of teaching and supervision of students' projects and teaching practice that rest on few teachers available reduce their effectiveness in teaching.

The findings from this study show that in private universities, infrastructures are more adequate than in public university. This agrees with the view of Omeje (2008) who noted that, the facilities and resources in our colleges of education and universities are in poor state, grossly inadequate to meet and sustain the required standard. 


\section{CONCLUSION}

On the general findings, the research concludes that even though both universities had less extent of implementation of the identified mechanisms, the private universities seem to record better implementation of moderation of examination, while both universities had less extent of implementation on other mechanisms. This is supported by results in tables 2-4. In summary, both public and private universities in South-East Nigeria do not follow NUC's laid down measures for quality assurance in education.

\section{RECOMMENDATIONS}

Based on the findings of this study the following recommendations were made:

1) University management in South-East Nigeria especially public universities should embark on monitoring scheme to ensure that departments implement moderation of examinations to a very high extent.

2) University management in South-East Nigeria should as a matter of importance, ensure that lecturers are exposed to various types of in-service programmes to update their skills, knowledge etc.

3) University management should ensure that adequate manpower is provided to match the number of students to avoid overloading the few available staff.

4) University management should ensure that adequate infrastructures are made available for effective teaching and learning to be ensured.

5) National Universities Commission (NUC) as a matter of urgency should take its job seriously by ensuring that all the mechanisms for quality assurance in education are thoroughly implemented by all the universities in Nigeria not only in South-East, Nigeria by all means including sanctions and denial of accreditation.

\section{REFERENCES}

- Adegbesan, S.O. (2011). Establishing quality assurance in Nigerian educational system: Implication for educational managers. Education Research and Reviews, 6(2), 146-151.

- $\quad$ Ajayi, I. A. \& Akindurite, I. O. (2007). The unresolved issues of quality assurance in Nigeria universities. Journal of Sociology and Education in Africa 6(1), 17-22.

- Akamobi, D. (2005). Assessment, for learning: beyond the black box. Cambridge: School of Education.

- Akindutire, E and Ajayi, P.O. (2007). "Evaluation of the Implementation of Physics Curriculum in South West Secondary Schools in Nigeria" Unpublished Research Monograph of the University of Ado-Ekiti.

- Anioke, B.O (2010). Adequate infrastructural provisions and quality attainment in business education. School of Vocational Education Journal 5(1), 234-241.

- $\quad$ Ekumayo, Z.A. (2010, April 6), Universities ranking: Nigerian keeps sliding. The Sun Pp. 27-28.

- Ezeani, A.N. \& Eze, L.O. (2010). Improving quality assurance in business education for actualization of the millennium development goals. Book of Readings 3(1), 146-150.

- $\quad$ Federal Republic of Nigeria (2004). National Policy on Education. Abuja: NERDC.

- Nakpodia, A.R. (2003). Career opportunities in education in Nigeria, Business Education Journal 2(3), $150-155$.

- National University Commission (2010). Manual of Accreditation procedure in Nigerian Universities: Criteria for accrediting a degree programme.

- Okebukola, P.A. (2011). Intensive retraining for graduates of universities for better quality and standard. A keynote Address at the first Oyo State Education Summit, Ibadan, July 10.

- Omeje, G.O. (2008). Improving and sustaining standards in Agricultural Education in colleges of education: The provision of facilities. In Enyi D., Meeting and Sustaining Standards in Colleges of Education, Ankpa: Cuca Publication.

- $\quad$ Qiang, A. \& Shiyan, W. (2007). Factors affecting the quality of post-internship of higher vocational education. National Bureau of Economic Research (Working Paper) 680-683. 